\title{
A Gene in the Pseudomonas syringae pv. tomato Hrp Pathogenicity Island Conserved Effector Locus, hopPtoA1, Contributes to Efficient Formation of Bacterial Colonies in Planta and Is Duplicated Elsewhere in the Genome
}

\author{
J. L. Badel, A. O. Charkowski, W.-L. Deng, and A. Collmer \\ Department of Plant Pathology, Cornell University, Ithaca, NY 14853 U.S.A.
}

Submitted 25 February 2002. Accepted 18 June 2002.

\begin{abstract}
The ability of Pseudomonas syringae to grow in planta is thought to be dependent upon the Hrp (type III secretion) system and multiple effector proteins that this system injects into plant cells. ORF5 in the conserved effector locus of the $P$. syringae pv. tomato DC3000 Hrp pathogenicity island was shown to encode a Hrp-secreted protein and to have a similarly secreted homolog encoded in an effector-rich pathogenicity island located elsewhere in the genome. These putative effector genes were designated hopPtoA1 and hopPtoA2, respectively. DNA gel blot analysis revealed that sequences hybridizing with hopPtoAl were widespread among $P$. syringae pathovars, and some strains, like $\mathrm{DC3000}$, appear to have two copies of the gene. uidA transcriptional fusions revealed that expression of hopPtoA1 and hopPtoA2 can be activated by the $\mathrm{HrpL}$ alternative sigma factor. hopPtoAI and hopPtoA1/hopPtoA2 double mutants were not obviously different from wild-type $P$. syringae pv. tomato DC3000 in their ability to produce symptoms or to increase their total population size in host tomato and Arabidopsis leaves. However, confocal laser-scanning microscopy of GFP (green fluorescent protein)-labeled bacteria in Arabidopsis leaves 2 days after inoculation revealed that the frequency of undeveloped individual colonies was higher in the hopPtoAl mutant and even higher in the hopPtoA1/hopPtoA2 double mutant. These results suggest that hopPtoA1 and hopPtoA2 contribute redundantly to the formation of $P$. syringae pv. tomato DC3000 colonies in Arabidopsis leaves.
\end{abstract}

The plant pathogenic bacterium Pseudomonas syringae is dependent on the Hrp (type III) protein secretion system to grow in the intercellular spaces of plant leaves and cause disease (Alfano and Collmer 1997). The Hrp system is thought to inject virulence (effector) proteins into plant cells, and collectively, these proteins are primary determinants of pathogenicity and host range (Kjemtrup et al. 2000). P. syringae is a host-

Corresponding author: Alan Collmer; Telephone: (607) 255-7843; Fax: (607) 255-4471; E-mail: arc2@ cornell.edu.

J. L. Badel and A. O. Charkowski contributed equally to this work.

Current address for A. O. Charkowski: Department of Plant Pathology, University of Wisconsin-Madison, Madison, WI 53706 U.S.A.

Nucleotide sequence data reported are available in the GenBank database under the accession numbers AF232006, AF232004, and AF469470. specific pathogen whose strains can be assigned to more than 40 pathovars based on their specificity for different plant species and to races within pathovars based on specificity for different cultivars of the host species. Incompatible interactions with resistant plant species or cultivars are marked by the hypersensitive response (HR), a rapid, defense-associated programmed death of plant cells in contact with the pathogen. The ability of $P$. syringae to elicit the HR is also dependent on the Hrp secretion system and the (largely unknown) collection of effector proteins that it injects into plant cells.

Although $P$. syringae mutants blocked in the Hrp secretion pathway are strikingly deficient in their plant interactions, the phenotypes of mutants deficient in individual effector protein genes are typically subtle and detectable only as quantitative reductions in pathogen growth in host tissues (Kjemtrup et al. 2000). However, effector protein genes can have a dramatic phenotype when transferred into a compatible race of $P$. syringae that is then inoculated into a host cultivar that carries a resistance $(R)$ gene that directs the defensive recognition of the effector (Keen 1990). Such recognition results in the HR instead of pathogenesis. Most effector genes known so far have been identified by this gain-of-function avirulence phenotype and are accordingly called $a v r$ genes. Unfortunately, it has not been possible to determine the full inventory of effector genes for any strain of $P$. syringae using plant reaction phenotypes, because mutant phenotypes for individual effector genes are either lacking or too difficult to detect in mutant screens and avirulence phenotypes are dependent on the unpredictable presence of cognate $R$ genes in test plants.

Properties of effector genes that are independent of plant reaction assays include association with pathogenicity islands, expression by Hrp promoters (which are activated by the HrpL alternative sigma factor), and secretion in culture by the Hrp system. Genes encoding the $P$. syringae Hrp secretion system are located on a pathogenicity island (Pai) with effector genes flanking both sides of the core six operons required for regulation and formation of the translocator apparatus (Alfano et al. 2000). An exchangeable effector locus (EEL), encoding diverse putative effector proteins, is located downstream of $h r p K$. A conserved effector locus (CEL), carrying at least 10 open reading frames (ORFs) that are conserved between $P$. syringae pv. syringae $\mathrm{B} 728 \mathrm{a}$ and $P$. syringae pv. tomato DC3000, is located on the other side of the core hrp/hrc cluster, flanking the $h r p R S$ operon. Deletion of the P. syringae pv. tomato DC3000 EEL slightly reduces bacterial growth in tomato, whereas deletion 
of avrE and the next five ORFs of the CEL abolishes pathogenicity in tomato (Alfano et al. 2000). The P. syringae pv. tomato DC3000 CEL contains a large intergenic region and seven operons, six of which are preceded by Hrp boxes (Alfano et al. 2000). The ORFs deleted in the CEL mutation encode AvrE and a putative chaperone, a second candidate effector and chaperone (ORF3 and ORF4), HrpW (a harpin), and an unknown protein (ORF5). ORF5 appears to be in a monocistronic operon preceded by a Hrp box and is the focus of this work.

The ability to travel the Hrp pathway is a general property of Hrp effector proteins that can be assayed using the Erwinia chrysanthemi Hrp system heterologously expressed in Escherichia coli (Ham et al. 1998). E. coli(pCPP2156) secretes in culture all $P$. syringae effectors that have been tested, including AvrB, AvrPto, AvrRpt2, and HopPsyA (Ham et al. 1998; Mudgett and Staskawicz 1999; van Dijk et al. 1999). HopPsyA has an avirulence phenotype when heterologously expressed in P. syringae pv. tabaci (Alfano et al. 1997; Collmer et al. 2000), but a cognate tobacco $R$ gene has not been defined. The protein has been designated HopPsyA (for Hrp-dependent outer protein of $P$. syringae pv. syringae) based on its secretion phenotype, as proposed for novel Hrp-secreted effector proteins (Alfano and Collmer 1997). It is also noteworthy that the $E$. coli(pCPP2156) Hrp secretion system secretes in culture the well-studied $P$. syringae effector AvrB, even though secretion of AvrB (even under conditions shown to be optimal for the secretion of other Avr/Hop proteins) has yet to be observed with P. syringae (van Dijk et al. 1999). Thus, the E. coli(pCPP2156) Hrp secretion system is well suited for testing candidate effectors for their ability to be secreted in a Hrp-dependent manner.

The lack of any phenotype in compatible (pathogenic) interactions with host plants for many $P$. syringae effector mutants has thwarted not only detection of new effectors but also study of the function of those effectors that have already been identified by their avirulence phenotype. A priori, we would expect effectors to suppress host defenses and promote nutrient release to bacteria in the apoplast. However, little is known about the biochemical activity or virulence function of $P$. syringae effectors, other than the ability of some to enhance growth in planta, as measured by colony-forming units released from crushed leaf tissue. Similarly, the reason that mutations in individual effector genes have only minor virulence phenotypes is most likely redundancy, but this has not been investigated by identification and mutagenesis of redundant effectors or by analysis of effector mutants with cell biological assays that might detect phenotypes too subtle for bacterial population assays.

In this work, we show that the $P$. syringae pv. tomato DC3000 CEL ORF5 product is secreted by the E. coli (pCPP2156) Hrp system (and, hence, is designated HopPtoA1), that there is a similarly secreted homolog (designated HopPtoA2) that is encoded elsewhere in the genome, that hopPtoA1 and hopPtoA2 are expressed in a HrpL-dependent manner, and that hopPtoAl/hopPtoA2 mutants have a novel phenotype in host leaves that is observable by confocal laserscanning microscopy of bacterial colonies labeled with Aequorea victoria green fluorescent protein (GFP).

\section{RESULTS}

hopPtoA1 is located in the Hrp Pai CEL, divergently oriented between ORF6 and $h r p W$.

The $P$. syringae pv. tomato DC3000 Hrp Pai CEL was isolated on two overlapping cosmids, pCPP2357 and pCPP3016 (Alfano et al. 2000). Seven putative operons, six of which are preceded by Hrp boxes, and one large intergenic region were identified (Fig. 1A). The operon encoding the 1,461-bp ORF5 now designated hopPtoAl is a single-gene operon preceded by Hrp box promoter sequence GGAACC-N16-CCACACA.

\section{Sequences hybridizing with hopPtoA1 are found in other phytopathogenic bacteria and elsewhere in the $P$. syringae pv. tomato $\mathrm{DC} 3000$ genome.}

We examined the distribution of hopPtoAl in P. syringae pathovars by DNA gel blot hybridization analysis, using a polymerase chain reaction (PCR)-amplified $P$. syringae pv. tomato DC3000 hopPtoAl fragment as a probe. The hopPtoAl probe hybridized to at least one distinct band for $P$. syringae pv. syringae B728a and 61 (weak), pv. angulata 9, glycinea races 1, 4, and 6, lachrymans 859, phaseolicola 343, and tabaci ATCC 11528. Very weak hybridization was observed with P. syringae pvs. papulans and pisi (Fig. 2A).

In this hybridization analysis, we noted that additional and unexpected DNA fragments were hybridizing with the hopPtoAl probe, suggesting the presence of a hopPtoAl homolog elsewhere in the $P$. syringae pv. tomato DC3000 genome. In order to confirm this possibility, total DNA from the $P$. syringae pv. tomato $\triangle \mathrm{CEL}$ mutant strain CUCPB5115 (Alfano et al. 2000), in which most of the CEL locus including hopPtoA1, is replaced with a $\Omega \mathrm{Sp} / \mathrm{Sm}^{\mathrm{r}}$ interposon, was digested with EcoRI and was probed with the PCR-amplified hopPtoA1. The probe hybridized distinctly and strongly to an approximately $7.5-\mathrm{kb}$ band (Fig. 2B), suggesting that $P$. syringae pv. tomato DC3000 carries a hopPtoAl homolog elsewhere in the genome (Fig. 1).

\section{hopPtoA2 is part of an apparent pathogenicity island that is not linked with the Hrp Pai.}

The $P$. syringae pv. tomato $\triangle \mathrm{CEL}$ mutant CUCPB5115 (Alfano et al. 2000) was digested with HindIII, and the 11.9-kb fragment hybridizing with a PCR-amplified hopPtoAl probe was cloned into pBluescriptII SK and was sequenced. A 1,464bp ORF sharing $81 \%$ identity to hopPtoAl was found in an apparent monocystronic operon preceded by the Hrp box promoter sequence GGAACC-N16-CTACACA and was designated hopPtoA2 (Figs. $1 \mathrm{~B}$ and $3 \mathrm{~A}$ ). Another ORF cloned in this fragment is preceded by a Hrp box, the 1,404-bp avrPphD $2_{\mathrm{Pto}}$. The first $500 \mathrm{bp}$ of this ORF show similarity ( $81 \%$ identity) to the first $500 \mathrm{bp}$ of the $P$. syringae pv. phaseo-
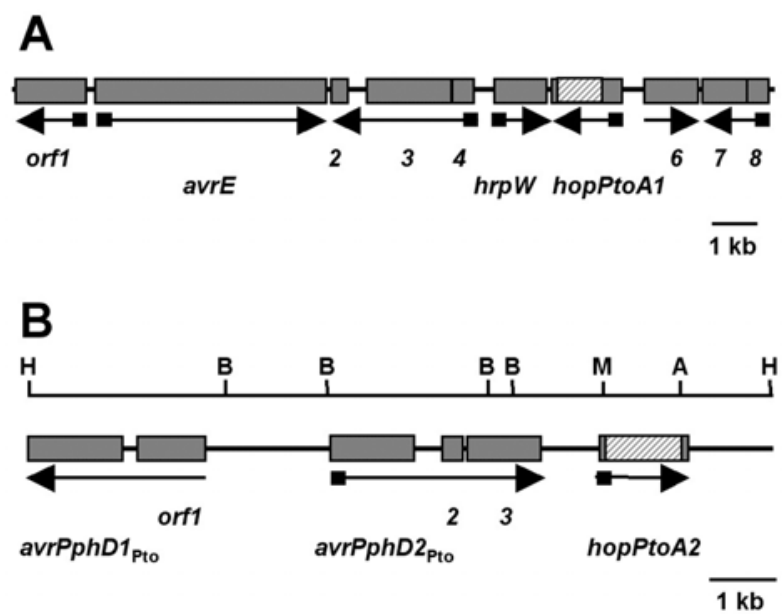

Fig. 1. Physical maps of the location of hopPtoAl and hopPtoA2 and mutations. A, Genetic organization of the CEL locus. B, Restriction and physical maps of the cloned fragment carrying hopPtoA2. Shaded boxes indicate genes; diagonally lined areas denote regions deleted in hopPtoA1 and hopPtoA2. Arrows indicate the direction of transcription; small black boxes denote the presence of a Hrp box. $\mathrm{H}=$ HindIII; $\mathrm{B}=$ $B a m \mathrm{HI} ; \mathrm{M}=M l u \mathrm{I}$; and $\mathrm{A}=A g e \mathrm{I}$. 
licola race 4 avirulence gene avrPphD (Arnold et al. 2001), with no detectable similarity for the rest of the coding sequence. The full length of the predicted amino acid sequence shows $98 \%$ identity to AvrPphD, $77 \%$ identity to the Xanthomonas campestris pv. vesicatoria Hrp-secreted protein XopB (Noël et al. 2001), and 34\% identity to a Ralstonia solanacearum AvrPphD-related protein (Salanoubat et al. 2002). Further upstream, beyond a long intergenic region, the nucleotide sequence of the 801-bp ORF1 shows greater than $92 \%$ identity to several transposaselike genes and insertion sequences found in Pseudomonas spp. (Chablain et al. 2001; Habe et al. 1996; Yamada et al. 1986).

The nucleotide sequence of the next truncated ORF upstream of ORF1, avrPphD1 $1_{\mathrm{Pto}}$, has $90 \%$ identity to the $P$. syringae pv. phaseolicola avrPphD (Arnold et al. 2001) and 79\% identity to the $X$. campestris pv. vesicatoria xopB (Noel et al. 2001). BLASTN and BLASTP searches with ORF2 and ORF3 sequences reveal no homologs in the databases, although it is noteworthy that the operon structure, a long ORF preceded by a much shorter one, commonly observed for chaperone/effector pairs, resembles those found for ORF4/ORF3 and ORF8/ORF7 in the CEL locus of the $P$. syringae pv. tomato DC3000 Hrp Pai (Fig. 1A). The average $\mathrm{G}+\mathrm{C}$ content $(55.2 \%)$ of the ORFs in

A
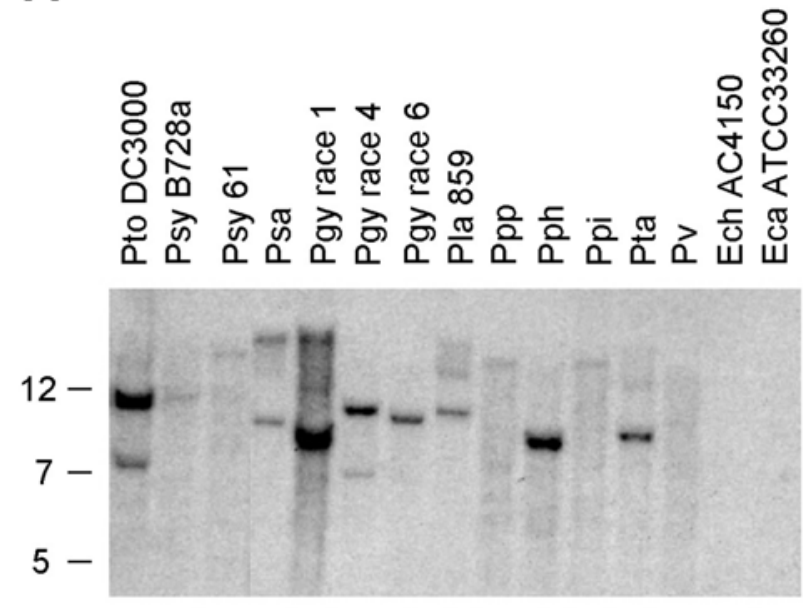

B

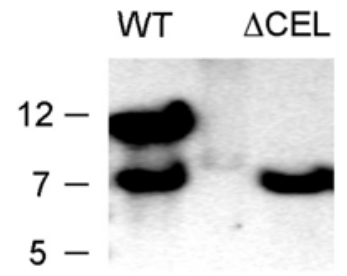

Fig. 2. DNA gel blot analysis of the hybridization of hopPtoAl to total DNA from other bacterial pathogens and to the Pseudomonas syringae pv. tomato $\triangle \mathrm{CEL}$ mutant. A, DNA from indicated pathogens was isolated, digested with EcoRI, resolved on a $0.5 \%$ agarose gel, transferred to an Immobilon-N membrane, and hybridized with a ${ }^{32} \mathrm{P}$-labeled hopPtoA1 probe. Pto $=P$. syringae pv. tomato $;$ Psy $=P$. Pseudomonas syringae $\mathrm{pv}$. syringae $; \mathrm{Psa}=P$. syringae pv. angulata $; \mathrm{Pgy}=P$. syringae pv. glycinea $;$ $\mathrm{Pla}=P$. syringae pv. lacrymans; $\mathrm{Ppp}=P$. syringae $\mathrm{pv}$. papulans $; \mathrm{Pph}=P$. syringae pv. phaseolicola $; \mathrm{Ppi}=P$. syringae $\mathrm{pv}$. pisi $; \mathrm{Pta}=P$. syringae pv. tabaci $; \mathrm{Pv}=P$. viridiflava $;$ Ech = Erwinia chrysanthemi $;$ and Eca $=$ Erwinia carotovora subsp. atroseptica. B, DNA from the $P$. syringae pv. tomato $\triangle \mathrm{CEL}$ mutant CUCPB5115 was subjected to DNA blot analysis as indicated above. WT $=P$. syringae pv. tomato DC3000; and $\triangle \mathrm{CEL}=$ $P$. syringae pv. tomato CUCPB5115. this region is significantly lower than the average of $59 \%$ of $P$. syringae (Palleroni 1984). Overall, the linkage of hopPtoA2 with several virulence-associated genes with a low $\mathrm{G}+\mathrm{C}$ content, some preceded by Hrp boxes, and also with sequences related to mobile genetic elements suggest that it is part of an apparent pathogenicity island.

The HopPtoA1 and HopPtoA2 proteins are highly similar.

hopPtoAl is predicted to encode a basic, alanine-rich ( 83 alanine residues, $17.1 \%$ ) 486-residue protein of $50.7 \mathrm{kDa}$ with a pI of 9.06. HopPtoA1 is like harpins in lacking cysteines (Fig. 3B) (Alfano and Collmer 1996; Alfano et al. 2000; He et al. 1993; Charkowski et al. 1998; Wei et al. 1992). However, unlike harpins, HopPtoA1 is not rich in glycine (35 glycine residues, $7.2 \%$ ) and has a relatively high $\mathrm{pI}$. hopPtoA2 encodes a protein with $77 \%$ identity to HopPtoA1. HopPtoA2 is predicted to be a 487-residue, basic, alanine-rich (73 alanine residues, $15.0 \%$ ) protein of $51.1 \mathrm{kDa}$ with a pI of 9.16. Like HopPtoA1, it has 35 glycine residues $(7.2 \%)$ but, unlike HopPtoA1, it has a cysteine residue at position 39 (Fig. 3B), which further suggests that HopPtoA proteins are not harpins. BLASTP searches with the predicted protein sequences of HopPtoA1 and HopPtoA2 of the GenBank database and of 86 microbial genome sequences currently deposited at NCBI reveal that they share 32 and $35 \%$ identity, respectively, to a putative transmembrane protein of Ralstonia solanacearum (Salanoubat et al. 2002). No discernible structural motifs were found in the HopPtoA1 and HopPtoA2 sequences using the tools InterProScan, Pfam, 3D-pssm, and Loopp.
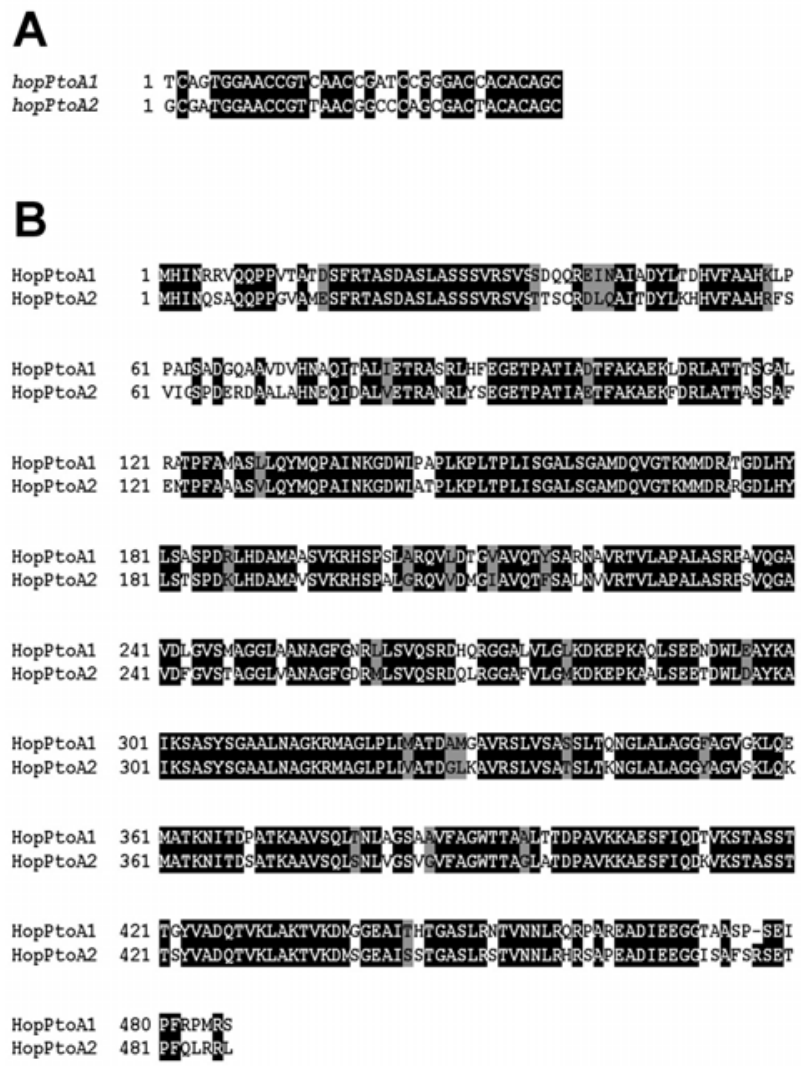

Fig. 3. Alignment of the nucleotide sequences of the hopPtoAl and hopPtoA 2 Hrp boxes and the amino acid sequences of the HopPtoA1 and HopPtoA2 proteins. A, Black boxes indicate conserved nucleotides in hopPtoAl and hopPtoA2 Hrp boxes and flanking nucleotides. B, In this alignment of the HopPtoA 1 and HopPtoA2 predicted protein sequences, black boxes indicate identical residues, gray boxes denote conserved residues, and a white background indicates different residues. Alignments were obtained with ClustalW and BoxShade. 
uidA transcriptional fusions reveal that hopPtoAl and hopPtoA2 can be expressed in a HrpL-dependent manner.

The presence of Hrp box sequences in the promoter regions of hopPtoAl and hopPtoA2 prompted us to test whether these genes are HrpL-inducible. We constructed single-copy, transcriptional fusions with uidA in the $P$. syringae pv. tomato DC3000 hrp/hrc mutant strain CUCPB5114 and expressed $h r p L$ constitutively under the control of the $n p t I I$ promoter in plasmid pCPP5032. pCPP5031, a plasmid carrying only the nptII promoter, was used as a $\mathrm{HrpL}^{-}$control (Fouts et al. 2002). We cultured the resulting strains, CUCPB5135(pCPP5031), CUCPB5135(pCPP5032), CUCPB5136(pCPP5031), and CUCPB5136(pCPP5032), in liquid AB-citrate medium (Chilton et al. 1974) and measured GUS activity. The GUS activity of CUCPB5135, carrying a hopPtoA1::uidA fusion, was 27 -fold higher in the presence of pCPP5032 than in the presence of pCPP5031. The GUS activity of CUCPB5136, carrying a hopPtoA2::uidA fusion, was 16-fold higher in the presence of pCPP5032 (Fig. 4). The fact that the expression of hopPtoA1 and hopPtoA2 is strongly induced in the presence of HrpL demonstrates that both genes have functional Hrp promoters.

\section{HopPtoA1 and HopPtoA2 are secreted in a Hrp-dependent manner.}

Because effector proteins travel the type III secretion pathway, we decided to check whether the proteins encoded by the hopPtoA genes are secreted by a Hrp secretion system. We constructed C-terminal fusions of hopPtoAl and hopPtoA2 with the FLAG epitope in pCPP3020 and pCPP5049, respectively, and introduced these plasmids into E. coli cells carrying the Erwinia chrysanthemi Hrp cluster in cosmid pCPP2156 and its mutant derivative pCPP2368. We then determined the distribution of flagged proteins in the supernatant and cell-bound fractions. Both HopPtoA1 and HopPtoA2 were detected in the supernatant fraction of $E$. coli cells carrying pCPP2156, but not in the supernatant fraction of $E$. coli cells carrying the $\mathrm{Hrp}^{-}$derivative pCPP2368 (Fig. 5). In order to rule out the possibility that the presence of the HopPtoA proteins in the supernatant fractions was due to cell lysis, we performed immunodetection using anti- $\beta$-galactosidase antibodies. The $\beta$-galactosidase protein was detected only in the cell-bound fraction, regardless of whether the E. coli cells carried pCPP2156 or pCPP2368 (Fig. 5). These results demonstrate that both HopPtoA1 and HopPtoA2 are secreted in a Hrp-dependent manner.

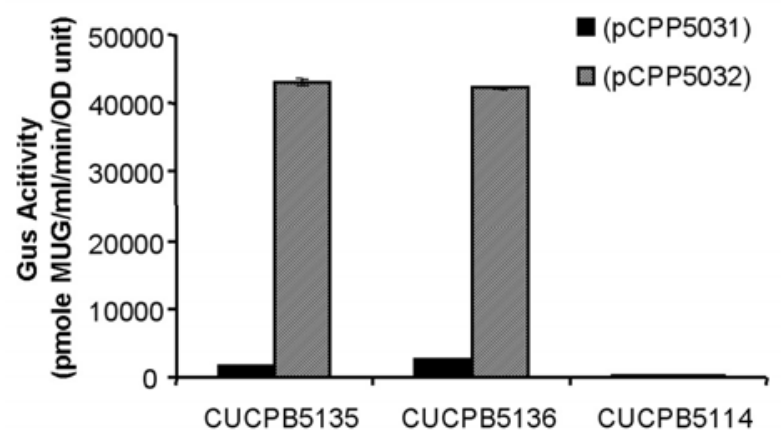

Fig. 4. Expression of hopPtoA1 and hopPtoA2 promoters in the presence of HrpL. Pseudomonas syringae pv. tomato strains CUCPB5135

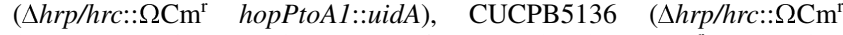
hopPtoA2::uidA), and CUCPB5114 (Ahrp/hrc:: $\left.\Omega \mathrm{Cm}^{\mathrm{r}}\right)$ carrying pCPP5031 (vector control; black bars) or pCPP5032 (HrpL ${ }^{+}$; shaded bars) were grown at $30^{\circ} \mathrm{C}$ for $6 \mathrm{~h}$ in liquid $\mathrm{AB}$-citrate and GUS activity determined. Vertical lines indicate standard errors.
hopPtoA1 and hopPtoA2 single and double mutants are not obviously reduced in their ability to grow in planta or to produce disease symptoms.

Marker-exchange mutagenesis was used to construct $P$. syringae pv. tomato mutants CUCPB5106 (LhopPtoAl::nptII), CUCPB5133 (DhopPtoA2::aadAl), and CUCPB5134 (DhopPtoA1::nptII $\Delta$ hopPtoA2::aadA1). Mutant constructions were confirmed with DNA gel blot analysis (data not shown). Tobacco leaves were infiltrated with wild-type $P$. syringae pv. tomato DC3000, CUCPB5106, CUCPB5133, and CUCPB5134 at three concentrations: optical density at $600 \mathrm{~nm}$ $\left(\mathrm{OD}_{600}\right)$ of 0.8 and 0.2 and a 1:10,000 dilution of the latter concentration. Leaves were examined $24 \mathrm{~h}$ later to determine the percentage of infiltrated tissue that was necrotic. No difference was observed between the wild type and any of the hopPtoA mutants (data not shown). The hopPtoAl gene did not inhibit the HR elicited by $P$. fluorescens(pHIR11), nor did it complement the HR-deficient phenotypes of pHIR11 hrpZ or hopPsyA mutants (data not shown). Thus, HopPtoA1 does not appear to be an analog of the HrpZ harpin or HopPsyA.

To determine if the hopPtoA mutants were reduced in virulence, tomato leaves inoculated with $P$. syringae pv. tomato DC3000, CUCPB5106, CUCPB5106(pCPP2475), CUCPB5133, CUCPB5133(pCPP5047), CUCPB5134, and CUCPB5134(pCPP2475, pCPP5047) were monitored over a period of 4 days. The hopPtoA mutants did not cause reduced symptoms in tomato leaves (Fig. 6A through D) and did not show reduction in bacterial multiplication compared with the wild type (Fig. 6E). Overexpression of hopPtoA genes in plasmids pCPP2475 and pCPP5047 did not result in changes in the ability of wild-type $P$. syringae pv. tomato DC3000 to grow in planta or to produce disease symptoms. Similar results were observed when Arabidopsis leaves were inoculated with the same strains (data not shown).

Confocal microscopy with GFP-labeled bacteria reveals that hopPtoA 1 and hopPtoA 2 double mutants are significantly reduced in their ability

to develop colonies in planta.

We transformed $P$. syringae pv. tomato DC3000 wild type and hopPtoA mutant strains CUCPB5106, CUCPB5133, and CUCPB5134 with pTB93F or pGFP-TIR and examined the sizes of the resultant GFP-labeled colonies that formed in

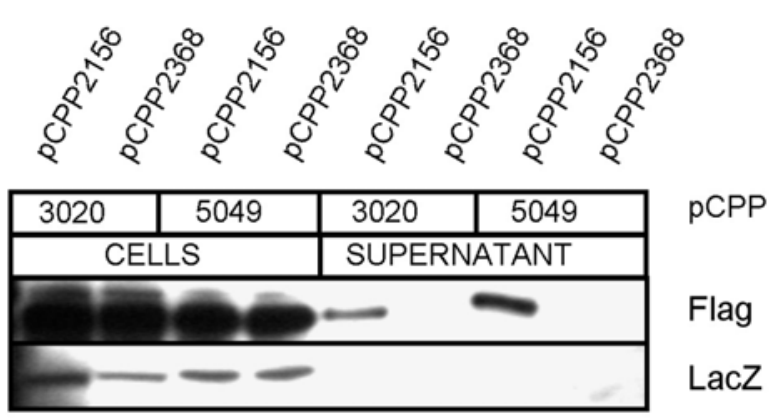

Fig. 5. Immunoblot analysis of the secretion of FLAG-epitope-tagged HopPtoA1 and HopPtoA2 by E. coli carrying the Erwinia chrysanthemi $h r p / h r c$ cluster. Bacteria were grown in liquid $\mathrm{LM}$ at $30^{\circ} \mathrm{C}$ to an $\mathrm{OD}_{600}$ of 0.4 and isopropyl- $\beta$-D-thiogalactopyranoside was added to a final concentration of $500 \mu \mathrm{M}$. Cultures were grown further to an $\mathrm{OD}_{600}$ of 0.8 and separated into cell-bound and supernatant fractions by centrifugation. Proteins were then resolved by sodium dodecyl sulfate-polyacrylamide gel electrophoresis, blotted, and immunostained with antibodies against the FLAG epitope and $\beta$-galactosidase. pCPP2156 carries the $E r$ winia chrysanthemi hrp/hrc cluster $\left(\mathrm{Hrp}^{+}\right)$, pCPP2368 is a pCPP2156 mutant derivative $\left(\mathrm{Hrp}^{-}\right)$, pCPP3020 expresses hopPtoA1, and pCPP5049 expresses hopPtoA2 under the control of the tac promoter. 
planta. In three separate experiments, we infiltrated Arabidopsis leaves with wild type and mutant strains and then observed the size of individual colonies in planta 2 days post infiltration using confocal laser-scanning microscopy. The hrcC mutant CUCPB5116 carrying pTB93F was also observed in Arabidopsis leaves. $P$. syringae hrcC mutants are blocked in type III secretion, have strong $\mathrm{Hrp}^{-}$phenotypes, and are unable to grow in planta (Alfano and Collmer 1997). The largest GFP-labeled colony or cell aggregate formed by the $h r c C$ mutant was approximately $250 \mu^{3}$, whereas the wild type produced colonies with a range of sizes and the majority of these were much larger than $250 \mu^{3}$ (data not shown). We accordingly used 250 $\mu \mathrm{m}^{3}$ as the threshold size for assessing the frequency of viable parasitic colonies in planta. The hopPtoAl mutant CUCPB5106 was also visible in a wide range of colony sizes, showing a higher frequency of colonies less than $250 \mu \mathrm{m}^{3}$ than in the wild type (Fig. 7B, Table 1). Although the frequency of colonies less than $250 \mu \mathrm{m}^{3}$ was not significantly higher than in the wild type in this experiment, it was consistently higher in several experiments, and complementation of the hopPtoAl mutation with pCPP2475 restored the wild-type frequency in all cases (data not shown). Significantly more colonies with less than $250 \mu^{3}$ were observed with hopPtoAl/hopPtoA2 double mutant CUCPB5134 $(p<0.001)$ (Table 1). Thus, CUCPB5134 appears significantly reduced in its ability to develop parasitic colonies in planta.

\section{DISCUSSION}

We have found the $P$. syringae pv. tomato DC3000 CEL ORF5 to encode a Hrp-secreted protein and to have a similarly secreted homolog in an effector-rich pathogenicity island that is not linked to the Hrp pathogenicity island CEL region. Expression of hopPtoAl and hopPtoA2 is activated by HrpL, and mutants have a phenotype observable by confocal laser-scanning microscopy that suggests a role for these proteins in colony development during pathogenesis. Several aspects of HopPtoA redundancy, secretion, expression, and contribution to virulence warrant further discussion.

Our previous observation that CEL ORF5 sequences are conserved in the distantly related $P$. syringae pv. tomato and $P$. syringae pv. syringae (Alfano et al. 2000) is consistent with the present DNA gel blot data suggesting that hopPtoA is widespread among $P$. syringae pathovars. Similarly, our recent genomewide analysis of ORFs downstream of Hrp box sequences in a genomic draft sequence of $P$. syringae pv. tomato DC3000 independently indicated the presence of a HopPtoA homolog
(Fouts et al. 2002). We show here that the high similarity between hopPtoA2 and hopPtoAl extends throughout the proteins and that multiple hopPtoA sequences are present in some, but not all, other $P$. syringae pathovars.

Interestingly, hopPtoA2 in DC3000 is linked to two P. syringae pv. phaseolicola arvPphD homologs (Arnold et al. 2001) and to sequences related to insertion elements. The average $G$ $+\mathrm{C}$ content $(55.2 \%)$ of the ORFs in this region is significantly lower than the average of $P$. syringae (59\%) (Palleroni 1984), and one of these ORFs, avrPphD2 $2_{\mathrm{Pto}}$, is also preceded by a Hrp box. avrPphD was originally isolated from $P$. syringae pv. phaseolicola race 4 through its ability to confer an avirulence phenotype to $P$. syringae pv. pisi on the normally susceptible pea cultivar Kelvedon Wonder (Wood et al. 1994). avrPphD is also widespread among $P$. syringae pathovars, but its mutation in $P$. syringae pv. phaseolicola race 7 does not result in reduction of bacterial multiplication or in virulence towards bean (Arnold et al. 2001). Noël and associates (2001), using cDNAAFLP (amplified fragment length polymorphism) analysis, recently identified an avrPphD homolog in $X$. campestris pv. vesicatoria, $x о p B$, which is also conserved among four $X$. campestris pv. vesicatoria strains tested. Mutation of $x o p B$ in $X$. campestris pv. vesicatoria 85-10 does not affect pathogenicity or bacterial multiplication in susceptible pepper Early Cal Wonder plants. Intriguingly, $x o p B$ is preceded by a Hrp box, which is characteristic of the Hrp regulons of $P$. syringae but not of Xanthomonas spp. Better knowledge of the conservation, redundancy, and genomic location of effector protein genes will, hopefully, provide clues to effector function. Our findings here suggest that hopPtoA may be part of both stable and mobile parts of the genome and that hopPtoA2 was acquired by $P$. syringae pv. tomato DC3000 more recently.

In $P$. syringae, the Hrp secretion machinery genes and all known effector genes are preceded by Hrp box promoters and are part of the Hrp regulon (Fouts et al. 2002). This regulon is activated by a regulatory cascade that includes the $\sigma^{54}$ enhancer-binding proteins HrpR and HrpS (Grimm et al. 1995; Hutcheson et al. 2001; Xiao et al. 1994) and the alternative sigma factor HrpL, which presumably interacts with Hrp boxes and activates hrp/hrc and effector genes (Innes et al. 1993; Shen and Keen 1993; Xiao and Hutcheson 1994; Xiao et al. 1994). We show that hopPtoAl and hopPtoA2 are activated by HrpL to similar levels. This result was surprising for several reasons. The hopPtoA2 hrp box sequence differs from the canonical sequence and from the hopPtoAl hrp box sequence in having a $\mathrm{T}$ in the -10 motif CTACACA, and attempts to detect HrpL-dependent induction of hopPtoA2 using genomewide
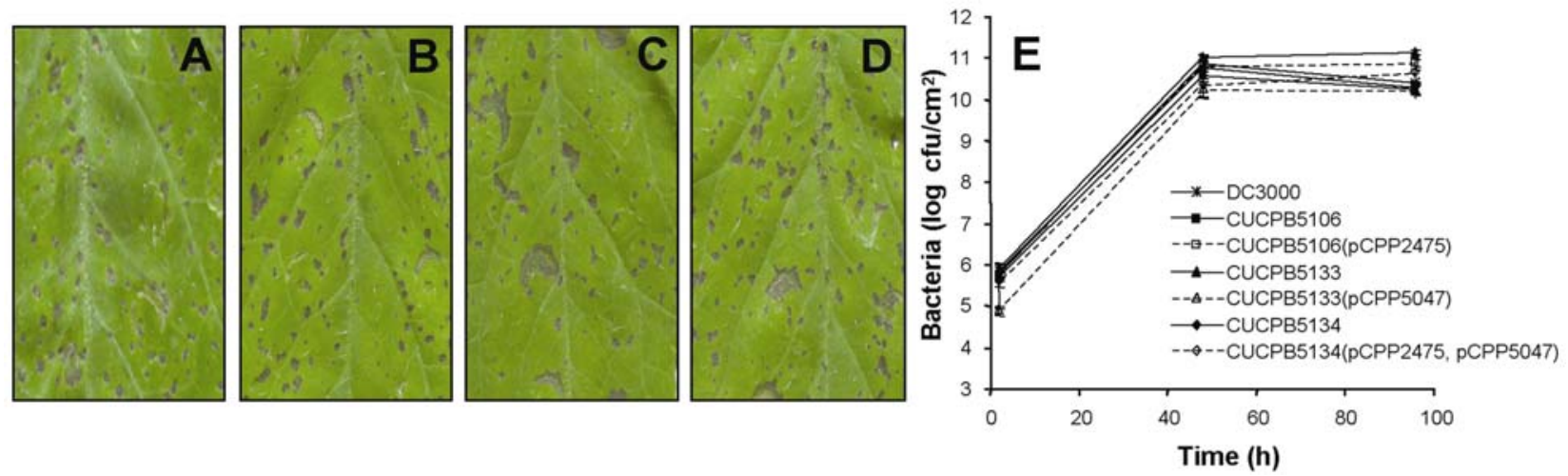

Fig. 6. Plant interaction phenotypes of Pseudomonas syringae pv. tomato mutants carrying deletions in hopPtoA1 (CUCPB5106), hopPtoA2 (CUCPB5133), and hopPtoAl/hopPtoA2 (CUCPB5134). Disease symptoms of tomato leaves 4 days after inoculation (10 4 CFU/ml) with A, P. syringae pv. tomato DC3000 wild type, B, CUCPB5106, C, CUCPB5133, and D, CUCPB5134. E, Growth in tomato of P. syringae pv. tomato DC3000, CUCPB5106, CUCPB5106(pCPP2475), CUCPB5133(pCPP5047), CUCPB5134, and CUCPB5134(pCPP2475, pCPP5047). Symbols represent the mean for three replications and vertical lines indicate standard errors. 
miniTn5gus reporter mutagenesis, microarray analysis, and Northern hybridization failed (Fouts et al. 2002). Possible explanations for this discrepancy are that hopPtoA2 was missed by reporter transposon mutagenesis, which did not saturate the genome, and that the hopPtoA2-uidA transcript may be more stable than the native hopPtoA2 mRNA that was assayed in the previous work.

The $P$. syringae Hrp system also secretes proteins that are likely to be translocation factors rather than effectors per se. Examples of these proteins are HrpA, which is the major component of the Hrp pilus (Roine et al. 1997), and the harpins HrpZ (He et al. 1993; Preston et al. 1995) and HrpW (Charkowski et al. 1998), which appear to be targeted to the plant cell wall (Hoyos et al. 1996) but also have effects on protoplasts and membranes (Lee et al. 2001). We observed that inoculation of tobacco leaves with the hopPtoAl (CUCPB5106), hopPtoA2 (CUCPB5233), and hopPtoAl/hopPtoA2 (CUCPB5134) mutant strains results in tissue collapse that is indistinguishable from that caused by the wild-type $P$. syringae pv. tomato DC3000. The fact that the hopPtoA mutants are able to elicit the HR when infiltrated into tobacco leaves indicates that the translocation process is not impaired and argues against hopPtoAl and hopPtoA2 encoding components of the secretion apparatus.

Harpins, such as the Erwinia amylovora HrpN and HrpW (Kim and Beer 1998; Wei et al. 1992;) and P. syringae HrpZ (He et al. 1993; Preston et al. 1995) and HrpW (Charkowski et al. 1998) proteins, appear to be redundant factors that are secreted by the Hrp system and that may promote effector translocation. HopPtoA 1 is like harpins in lacking cysteine residues; however, several lines of evidence argue against HopPtoA proteins being harpins. First, HopPtoA2 has a cysteine residue at position 39. Second, HopPtoA proteins are not rich in glycine residues, and they have a basic, rather than acidic, pI. Third, hopPtoAl expressed in trans does not complement the HR minus phenotype of a $P$. fluorescence 55(pHIR11) hrpZ nonpolar deletion mutant nor does it interfere with elicitation of HR in tobacco leaves by $P$. fluorescence 55(pHIR11).

Therefore, the HopPtoA proteins probably function as effectors. However, as with many effectors, standard assays failed to reveal any significant reduction in virulence or bacterial multiplication in planta of hopPtoA1, hopPtoA2, or hopPtoAl/hopPtoA2 mutants. We inoculated tomato and Arabidopsis plants by infiltration using a blunt syringe and by dipping in inoculum of concentrations ranging from $10^{2}$ to $10^{5}$ $\mathrm{CFU}$ per ml. To date, evidence of the contribution to virulence
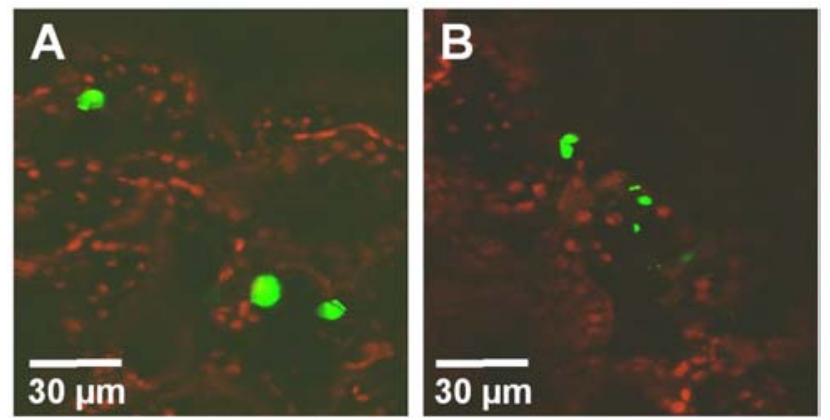

Fig. 7. Confocal laser-scanning microscopy analysis of the development of green fluorescent protein (GFP)-labeled Pseudomonas syringae pv. tomato and hopPtoA mutants in Arabidopsis leaves. Leaves were infiltrated with $10^{6} \mathrm{CFU} / \mathrm{ml}$ suspensions of bacteria carrying pTB83F and were observed after $40 \mathrm{~h}$ by confocal laser-scanning microscopy. Light from two photomultiplier tubes was collected to detect either red light from chloroplast autofluorescence or green light from GFP. A, GFP-labeled P. syringae pv. tomato DC3000; B, GFP-labeled hopPtoA1 mutant CUCPB5106. of $P$. syringae pv. tomato DC3000 effectors using such methods has been obtained indirectly from mutations in gene homologs present in less virulent $P$. syringae pv. tomato strains, e.g., PT23 (Lorang et al. 1994), or from less virulent strains, e.g., T1, heterologously expressing the effector gene (Shan et al. 2000). Moreover, increased virulence of $P$. syringae pv. tomato DC3000 expressing heterologous effector genes has been observed only when challenging plants with enhanced disease resistance, e.g., Arabidopsis No-0 or coil mutant, or through the use of transgenic plants expressing the effector gene (Chen et al. 2000). The reason that mutations in individual effector genes have little or no virulence phenotype is most likely redundancy, but this has not been experimentally tested.

Our DNA gel blot and genomic analyses both indicate that $P$. syringae pv. tomato DC3000 contains only two hopPtoA homologs. We mutated both of these but did not detect any phenotype, using standard assays for symptom production and total bacterial growth in planta. Consequently, we tried a cell biological assay capable of detecting subtle changes in the parasitic behavior of the mutants. Specifically, we inoculated Arabidopsis leaves with GFP-labeled wild-type and mutant strains and observed the development of unperturbed individual colonies. We found that, relative to the wild type, the frequency of undeveloped colonies was higher in the hopPtoAl mutant and even higher in the hopPtoAl/hopPtoA2 double mutant. These results suggest that hopPtoAl and hopPtoA2 contribute redundantly to the formation of $P$. syringae pv. tomato DC3000 colonies in Arabidopsis leaves, and they validate confocal laser-scanning microscopy analysis of GFP-labeled bacterial colonies as a sensitive and informative assay for effector mutant performance in planta.

Why many hopPtoA1/hopPtoA2 mutant cells in a leaf still parasitically succeed and produce colonies as large as the wild type is unclear. Perhaps $P$. syringae pv. tomato DC3000 produces other effectors that have a different structure but a similar function. Alternatively, infection sites in a leaf may be heterogeneous, with only a fraction requiring the HopPtoA proteins for colony formation. To resolve this issue, we need to better understand the inventory of effector proteins in P. syringae pv. tomato DC3000 and the interactions of individual bacterial and plant cells. This work represents a first step in exploring the function of the HopPtoA proteins and in using cell biological tools to define stages in $P$. syringae pathogenesis to which individual effectors (or effector families) may be assigned.

\section{MATERIALS AND METHODS}

Bacterial strains, plasmids, and media.

Bacterial strains, cosmid clones, and plasmids used in this study are described in Table 2. E. coli cells were grown in LM (Hanahan 1985) or terrific broth (Sambrook et al. 1989) at $37^{\circ} \mathrm{C}$,

Table 1. Colony sizes of green fluorescent protein-labeled Pseudomonas syringae pv. tomato DC3000 wild type and hopPtoA mutant strains in Arabidopsis $^{\mathrm{a}}$

\begin{tabular}{llll}
\hline \multirow{2}{*}{ Strain } & \multicolumn{3}{c}{ Colony size $\left(\boldsymbol{\mu m}^{\mathbf{3}}\right)$} \\
\cline { 2 - 4 } CUCPB5106 (hopPtoA1) & $<\mathbf{2 5 0}$ & $\geq \mathbf{2 5 0}$ & Total \\
\hline CUCPB5134 (hopPtoA1/hopPtoA2) & 209 & 506 & 715 \\
Wild type & $(29.2)^{\mathrm{b}}$ & $(70.8)$ & \\
& $(43.0)$ & 385 & 675 \\
& 247 & 711 & 958 \\
\hline
\end{tabular}

\footnotetext{
a Table probability $p<0.0001$ (chi-square statistics).

${ }^{\mathrm{b}}$ Values in parentheses indicate row percentages.

c Statistically different from wild type $(p<0.001$, chi-square statistics).
} 
and $P$. syringae cells were grown in King's B (King et al. 1954) or in hrp-derepressing fructose minimal medium (Huynh et al. $1989)$ at $30^{\circ} \mathrm{C}$. Except where noted, E. coli DH5 and E. coli DH5 $\alpha$ (Life Technologies, Grand Island, NY, U.S.A.) were used as hosts for DNA clones and the pBluescriptII SK plasmid (Stratagene, La Jolla, CA, U.S.A.) was used as a vector. The nucleotide sequence of the CEL of the $P$. syringae tomato DC3000 $h r p / h r c$ cluster was determined using pv. subclones of pCPP2357 and pCPP3016. These cosmids were isolated as described by Alfano and associates (2000). GFP was constitutively expressed in plasmids pGFP-TIR (Miller and Lindow 1997) or pTB93F (Gage et al. 1996). Antibiotics were used at the following concentrations ( $\mu \mathrm{g} / \mathrm{ml})$ : ampicillin, 100; kanamycin 50; rifampin, 50; gentamycin, 10; tetracycline, 10; spectinomycin, 50.

\section{Recombinant DNA techniques.}

DNA manipulations and PCR were performed according to standard protocols (Sambrook et al. 1989; Innis et al. 1990). Oligonucleotide primers for sequencing or PCR were purchased from Integrated DNA Technology (Coralville, IA, U.S.A.) and are described in Table 3. PCR was performed with Vent or Deep Vent polymerases (New England Biolabs, Beverly, MA, U.S.A.). All DNA sequencing was done at the Cornell Biotechnology Center with an automated DNA sequencer, model 373A (Applied Biosystems, Foster City, CA, U.S.A.). DNA sequences were analyzed with the DNASTAR (Madison, WI, U.S.A.) software package. Database searches were performed using gapped BLASTN, BLASTP, and BLASTX (Altschul et al. 1997).

Table 2. Strains and plasmids used in this study

\begin{tabular}{|c|c|c|}
\hline Designation & Relevant characteristics $^{\mathbf{a}}$ & Reference or source \\
\hline \multicolumn{3}{|l|}{ Strains } \\
\hline Escherichia coli $\mathrm{DH} 5 \alpha$ & SupE44 $\triangle l a c U 169$ (f80 lacZAM15) hsdR17 recA1 endA1 gyrA96 thi-1 relA1, $\mathrm{Nx}^{\mathrm{r}}$ & Life Technologies \\
\hline \multicolumn{3}{|c|}{ Pseudomonas syringae pv. tomato } \\
\hline DC3000 & Wild type, Rif $^{\mathrm{r}}$ & Cuppels 1986 \\
\hline CUCPB5106 & ShopPtoAl::nptII, $\operatorname{Rif}^{\mathrm{r}} \mathrm{Km}^{\mathrm{r}}$ & This study \\
\hline CUCPB5114 & $\Delta h r p / h r c:: \Omega \mathrm{Cm}^{\mathrm{r}}, \mathrm{Rif}^{\mathrm{r}} \mathrm{Cm}^{\mathrm{r}}$ & Fouts et al. 2002 \\
\hline CUCPB5115 & $\triangle C E L:: \Omega \mathrm{Sp} / \mathrm{Sm}^{\mathrm{r}}, \mathrm{Rif}^{\mathrm{r}} \mathrm{Sp}^{\mathrm{r}}$ & Alfano et al. 2000 \\
\hline CUCPB5116 & $h r c C: \because \operatorname{Tn} 5 C m, \operatorname{Rif}^{\mathrm{T}} \mathrm{Cm}^{\mathrm{r}}$ & Yuan and He 1996 \\
\hline CUCPB5133 & AhopPtoA2::aadA1, $\operatorname{Rif}^{\mathrm{T}} \mathrm{Sp}^{\mathrm{r}}$ & This study \\
\hline CUCPB5134 & ShopPtoA1::nptII $\triangle$ hopPtoA2::aadA1, $\operatorname{Rif}^{\mathrm{r}} \mathrm{Km}^{\mathrm{r}} \mathrm{Sp}^{\mathrm{r}}$ & This study \\
\hline CUCPB5135 & ShopPtoA1::uidA1::nptII, $\operatorname{Rif}^{\mathrm{r}} \mathrm{Km}^{\mathrm{r}}$ derivative of CUCPB5114 & This study \\
\hline CUCPB5136 & ShopPtoA2::uidA1::nptII, $\operatorname{Rif}^{\mathrm{T}} \mathrm{Km}^{\mathrm{r}}$ derivative of CUCPB5114 & This study \\
\hline P. fluorescence 55 & Wild type, $\mathrm{Nx}^{\mathrm{r}}$ & Huang et al. 1988 \\
\hline \multicolumn{3}{|l|}{ Plasmids } \\
\hline pBluescriptII SK or KS & ColE1 mcs-lacZ, Ap ${ }^{\mathrm{r}}$ & Stratagene \\
\hline pRK415 & Broad-host-range vector unstable in the absence of selection, $\mathrm{Tc}^{\mathrm{r}}$ & Keen et al. 1988 \\
\hline pCPP45 & Broad-host-range, pCPP30 with RP4 par region in Stu I site, $\mathrm{Tc}^{\mathrm{r}}$ & D. W. Bauer (Cornell University) \\
\hline pUCP24 & Escherichia-Pseudomonas shuttle vector with aacCl and $\operatorname{laz} \alpha, \mathrm{Gm}^{\mathrm{r}}$ & Olsen et al. 1982 \\
\hline pFLAG-CTC & For construction of C-terminal fusions to the FLAG epitope, $A p^{r}$ & Kodak \\
\hline pCPP54 & pCPP33 derivative carrying $S a c B$ and $S a c R$ from pUM24, $\mathrm{Tc}^{\mathrm{r}}$ & D. W. Bauer (Cornell University) \\
\hline pJQ200SK & Suicide vector with $l a c Z \alpha$ carrying $s a c B, \mathrm{Gm}^{\mathrm{r}}$ & Quandt and Hynes 1993 \\
\hline $\mathrm{pHP} 45 \Omega \mathrm{Sp} / \mathrm{Sm}$ & pHP45 carrying $\Omega \mathrm{Sp} / \mathrm{Sm}^{\mathrm{r}}$ for interposon mutagenesis, $\mathrm{Ap}^{\mathrm{r}} \mathrm{Sp}^{\mathrm{r}}$ & Prentki and Krisch 1984 \\
\hline pGFP-TIR & pGreen carrying TIR, $\mathrm{Gm}^{\mathrm{r}}$ & Miller and Lindow 1997 \\
\hline pTB93F & ptrp-GFP-S65T in pMB393, $\mathrm{Sp}^{\mathrm{r}}$ & Gage et al. 1996 \\
\hline pCPP2277 & pBluescriptII SK carrying a uidA1::nptII cassette & D. W. Bauer (Cornell University) \\
\hline pCPP2988 & $\begin{array}{l}\text { pBluescript II SK(-) carrying } 1.5 \text { HindIII-SacI fragment from pRZ102 with nptII } \\
\text { lacking terminator, } \mathrm{Ap}^{\mathrm{r}} \mathrm{Km}^{\mathrm{r}}\end{array}$ & Alfano et al. 1996 \\
\hline pHIR11 & pLAFR3 derivative carrying $25 \mathrm{~kb}$ of $P$. syringae $61 \mathrm{hrp} / \mathrm{hrc}$ cluster, $\mathrm{Tc}^{\mathrm{r}}$ & Huang et al. 1988 \\
\hline рCРP2156 & pCPP19 derivative carrying Erwinia chrysanthemi hrp/hrc cluster, $\mathrm{Sp}^{\mathrm{r}}$ & Ham et al. 1998 \\
\hline pCРP2368 & pCPP2156::Tn5Cm that has HR phenotype, $\mathrm{Sp}^{\mathrm{r}} \mathrm{Cm}^{\mathrm{r}}$ & Ham et al. 1998 \\
\hline pCPP2357 & $\begin{array}{l}\text { Cosmid clone, pCPP } 47 \text { carrying from } h r c J \text { to } h r p W \text { of the } P \text {. syringae pv. tomato } \\
\text { DC } 3000 \text { Hrp pai, Tcr. }\end{array}$ & Alfano et al. 2000 \\
\hline pCPP3016 & $\begin{array}{l}\text { Cosmid clone, pCPP } 47 \text { carrying } 5^{\prime} \text { end of } a v r E \text { to CEL edge of the P. syringae pv. } \\
\text { tomato DC } 3000 \mathrm{Hrp} \text { pai, } \mathrm{Tc}^{\mathrm{r}}\end{array}$ & Alfano et al. 2000 \\
\hline pCPP2435 & $\begin{array}{l}\text { pBluescript II SK(+) carrying 11-kb EcoRI fragment from pCPP3016; contains avrE, } \\
\text { hrpW, hopPtoA1, } \mathrm{Ap}^{\mathrm{r}}\end{array}$ & Alfano et al. 1996 \\
\hline pCPP2437 & pBluescript II SK carrying 4.2 MfeI fragment from pCPP3016, $\mathrm{Ap}^{\mathrm{r}}$ & This study \\
\hline pCPP2476 & pCPP2437 4hopPtoA1::nptII, $\mathrm{Ap}^{\mathrm{r}} \mathrm{Km}^{\mathrm{r}}$ & This study \\
\hline pCPP2455 & pRK415 carrying BamHI fragment from pCPP2476, $\mathrm{Tc}^{\mathrm{r}} \mathrm{Km}^{\mathrm{r}}$. & This study \\
\hline pCPP2475 & pUCP24 carrying $3.0-\mathrm{kb} S p h \mathrm{I}$ fragment from pCPP2435, $\mathrm{Gm}^{\mathrm{r}}$ & This study \\
\hline pCPP3020 & pFLA-CTC carrying hopPtoAl, $\mathrm{Ap}^{\mathrm{r}}$ & This study \\
\hline рСРP3021 & pBluescriptII SK carrying hopPtoAl, Ap ${ }^{\mathrm{r}}$ & This study \\
\hline pCPP5031 & pRK415 carrying PnptII, $\mathrm{Tc}^{\mathrm{r}}$ & Fouts et al. 2002 \\
\hline pCPP5032 & pRK415 carrying $P$. syringae pv. tomato DC3000 hrpL under control of PnptII, $\mathrm{Tc}^{\mathrm{r}}$ & Fouts et al. 2002 \\
\hline pCPP5042 & pBluescriptII SK carrying 11.9-kb fragment from CUCPB5115, Ap ${ }^{\mathrm{r}}$ & This study \\
\hline pCPР5043 & pBluescriptII SK carrying 4.1-kb BamHI fragment from pCPP5042, Ap ${ }^{\mathrm{r}}$ & This study \\
\hline pCPP5044 & pBluescriptII SK carrying aadAl from $\mathrm{pHP} 45 \Omega \mathrm{Sp} / \mathrm{Sm}^{\mathrm{r}}, \mathrm{Ap}^{\mathrm{r}} \mathrm{Sp}^{\mathrm{r}}$ & This study \\
\hline pCPР5045 & pCPР5043 AhopPtoA2::aadA1, $\mathrm{Ap}^{\mathrm{r}} \mathrm{Sp}^{\mathrm{r}}$ & This study \\
\hline рCРP5046 & pCPP54 carrying Bam HI fragment from pCPP5045, $\mathrm{Tc}^{\mathrm{r}} \mathrm{Sp}^{\mathrm{r}}$ & This study \\
\hline pCPP5047 & pCPP45 carrying Bam HI fragment from pCPP5043, $\mathrm{Tc}^{\mathrm{r}}$ & This study \\
\hline pCPP5048 & pBluescriptII SK carrying hopPtoA2, Ap ${ }^{\mathrm{r}}$ & This study \\
\hline pCPP5049 & pFLAG-CTC carrying hopPtoA2, Ap ${ }^{\mathrm{r}}$ & This study \\
\hline pCPP5050 & pJQ200SK carrying hopPtoA1::uidA1::nptII construct, $\mathrm{Gm}^{\mathrm{r}} \mathrm{Km}^{\mathrm{r}}$ & This study \\
\hline pCPP5051 & pJQ200SK carrying hopPtoA2::uidA1::nptII construct, $\mathrm{Gm}^{\mathrm{r}} \mathrm{Km}^{\mathrm{r}}$ & This study \\
\hline
\end{tabular}

a Ap, ampicillin; Cm, chloramphenicol; Gm, gentamycin; Km, kanamycin, Nx, nalidixic acid; Tc, tetracycline; Sp, spectinomycin; Sm, streptomycin, Rif, rifampicin. 
Construction of the hopPtoA1 marker exchange mutation in $P$. syringae pv. tomato.

A 4.2-kb MfeI fragment containing hrpW, hopPtoAl, and part of ORF6 (Fig. 1A) was subcloned from pCPP3016 into the EcoRI site of pBluescriptII SK to make pCPP2437. pCPP2437 was digested with NarI, the DNA overhanging ends were digested with Klenow, and the fragment was ligated to a SmaI fragment carrying a terminatorless $n p t I I$ gene from pCPP2988 to construct pCPP2476. A BamHI fragment containing the nptII cassette plus $P$. syringae pv. tomato DC3000 flanking DNA from pCPP2476 was inserted into pRK415 to construct pCPP2455. The mutated hopPtoAl was marker-exchanged into $P$. syringae pv. tomato $\mathrm{DC} 3000$ to construct strain CUCPB5106. The mutation was confirmed with DNA gel blot analysis. For complementation of hopPtoAl, a 3.0-kb SphI fragment from pCPP2435 carrying hopPtoAl was ligated into the SphI site of pUCP24 to construct pCPP2475, which should express hopPtoAl under the control of its native promoter.

\section{Cloning of hopPtoA2 and construction of its marker} exchanged mutations in $P$. syringae pv. tomato.

Genomic DNA of the $P$. syringae tomato $\triangle \mathrm{CEL}$ mutant CUCPB5115 was digested with HindIII; the 11.9-kb fragment carrying hopPtoA2 was cloned into pBluescriptII SK to construct pCPP5042 and was sequenced. For gene replacement, pCPP5042 was digested with $B a m \mathrm{HI}$ and the 4.1-kb fragment containing hopPtoA2 subcloned into pBluescriptII SK to obtain pCPP5043. The aadAl gene including its native promoter and no transcription termination signals was PCR amplified from $\mathrm{pHP} 45 \Omega \mathrm{Sp} / \mathrm{Sm}^{\mathrm{r}}$ using primers p0809 and p0810. The amplified fragment was cloned into the HindIII sites of pBluescriptII SK to construct pCPP5044. pCPP5043 was digested with AgeI and $M l u \mathrm{I}$ and the $1.2-\mathrm{kb}$ internal fragment from hopPtoA2 was replaced with the terminatorless aadA1 from pCPP5044 to construct pCPP5045. The BamHI fragment containing the aadAl cassette plus $P$. syringae pv.. tomato DC3000 flanking DNA from pCPP5045 was subcloned into pCPP54 to construct pCPP5046. The mutated hopPtoA2 was marker-exchanged into P. syringae pv. tomato DC3000 and the hopPtoAl mutant strain CUCPB5106 to construct strains CUCPB5133 and CUCPB5134, respectively. The mutations were confirmed with DNA gel blot analyses. For complementation of hopPtoA2, the BamHI fragment from pCPP5043 carrying hopPtoA2 was ligated into the BamHI site of pCPP45 to construct pCPP5047, which should express hopPtoA2 under the control of its native promoter.

\section{Construction of hopPtoA1 and hopPtoA2 fused to the FLAG epitope.}

hopPtoAl was amplified from pCPP3016 with Vent polymerase using primers p0408 and p0098 and ligated into the
EcoRI and SalI sites of pBluescriptII SK to construct pCPP3021. pCPP3021 was digested with NdeI and SalI, and the fragment subcloned into pFLAG-CTC (Kodak, Rochester, NY, U.S.A.) to construct pCPP3020. hopPtoA2 was PCR amplified from pCPP5042 with Vent polymerase using primers p0820 and p0821 and ligated into the HindIII and SalI sites of pBluescriptII SK to construct pCPP5048. pCPP5048 was digested with $N d e I$ and EcoRI, and the fragment subcloned into pFLAG-CTC (Kodak) to construct pCPP5049. pCPP3020 and pCPP5049 constructs produce HopPtoA1 and HopPtoA2 fused to the FLAG epitope under the control of the tac promoter.

\section{Construction of genomic uidA transcriptional fusions of hopPtoA1 and hopPtoA2.}

To construct a transcriptional fusion of hopPtoAl with uidA, a 2.1-kb fragment containing the first $246 \mathrm{bp}$ of the coding region of hopPtoAl and upstream sequences (Fig. 1A) was amplified from pCPP3016 with Deep Vent polymerase using primers p0885 and p0886. A 2.2-kb fragment including the last $477 \mathrm{bp}$ of the hopPtoAl coding region and downstream sequence was amplified using primers p0887 and p0888. The digested fragments were ligated to an uidA::nptII cassette from pCPP2277 digested with $X b a \mathrm{I}$ and $X h o \mathrm{I}$ and to pJQ200SK digested with ApaI and SacI to obtain pCPP5050. pCPP5050 was maker-exchanged into CUCPB5114 to obtain strain CUCPB5135. To construct hopPtoA2 fused to $u i d \mathrm{~A}$, a 2.2-kb fragment of sequence including the first $389 \mathrm{bp}$ of the coding region of hopPtoA2 and upstream sequences (Fig. 1B) was amplified from pCPP5042 with primers p0881 and p0882. A 1.7-kb fragment including the last $416 \mathrm{bp}$ of the coding region of hopPtoA 2 and downstream sequence was amplified with primers p0883 and p0884. The digested fragments were ligated to uidA-nptII and pJQ200SK as indicated above to construct pCPP5051. pCPP5051 was maker-exchanged into CUCPB5114 to obtain strain CUCPB5136. CUCPB5135 and CUCPB5136 were transformed with pCPP5032, which expresses $h r p L$ under the control of the nptII promoter, and with pCPP5031, which is the vector carrying only the nptII promoter.

\section{Protein secretion assays.}

To determine if HopPtoA1 and HopPtoA2 are secreted via the Hrp system, E. coli DH5 $(\mathrm{pCPP} 2156)$ and E. coli DH5 $\alpha(\mathrm{pCPP} 2368)$ were transformed with pCPP3020 and pCPP5049. pCPP2156 carries a functional type III secretion system from Erwinia chrysanthemi. pCPP2368 is a pCPP2156 derivative with a mini-Tn5Cm ${ }^{\mathrm{r}}$ in the $h r p J$ operon (Ham et al. 1998). Cells were grown overnight on LM agar plus appropriate antibiotics at $37^{\circ} \mathrm{C}$, scraped from the plates, washed twice with LM liquid medium, and resuspended in $40 \mathrm{ml} \mathrm{LM}$ plus antibiotics to an $\mathrm{OD}_{600}$ of 0.2 . The cultures were grown at $30^{\circ} \mathrm{C}$ until the $\mathrm{OD}_{600}$ reached 0.4 , then isopropyl- $\beta$-D-thiogalacto-

Table 3. Primers used in this study ${ }^{\mathrm{a}}$

\begin{tabular}{|c|c|c|}
\hline Primer & Sequence $\left(5^{\prime}-3^{\prime}\right)$ & Restriction enzymes \\
\hline p0098 & TCACAGTTGTCGACCGACCGCATAGG & $\underline{\text { SalI }}$ \\
\hline p0408 & GAGGGAATTCATATGCACATCAACCGA & EcoRI and $N d e$ I \\
\hline p0809 & CGCCGCGAAGCTTACCGGTCTTGAACGAAT & HindIII and $\overline{A g e} \mathrm{I}$ \\
\hline p0810 & GCTCGTAAGCTTGACGCGTCAGAAATGCCT & HindIII and $\overline{M l u I}$ \\
\hline p0820 & ACCGAAGCTTATTCATATGCACATCAACCA & HindIII and $\overline{N d e I}$ \\
\hline p0821 & TGCAACCCACAGGCGAATTCCAAACG & EcoRI \\
\hline p0881 & GGCAGTGTATGGGGAGCTCTCAATCT & $\underline{S a c I}$ \\
\hline p0882 & CGAGGCAGCGGCATCTAGAGTGTTC & $\underline{\underline{X b a} \mathrm{I}}$ \\
\hline p0883 & GGTGCTCGAGCCGGGGTAAGTAAGT & $\underline{X h o I}$ \\
\hline p0884 & TTGACCTGGGCCCGGGCGTGACA & $\overline{A p a \mathrm{I}}$ \\
\hline p0885 & CGATCAGCTCTAGAATCTGCGCATTGTGTA & $\underline{X b a \mathrm{I}}$ \\
\hline p0886 & СCTTCTTTCACGAGCTCGAGGACTATCA & $\overline{S a c \mathrm{I}}$ \\
\hline p0887 & CTGAGTGCGGGGCCCTCGTTGATAA & $\overline{A p a I}$ \\
\hline p0888 & AATGGGTGCTCGAGGAAGCCTGGTGT & $\underline{X h o I}$ \\
\hline
\end{tabular}

\footnotetext{
${ }^{\mathrm{a}}$ Restriction sites are indicated with boldface and underline.
} 
pyranoside was added to a final concentration of $500 \mu \mathrm{M}$, and incubation was continued until the $\mathrm{OD}_{600}$ was 0.8 . The cellbound and supernatant proteins were prepared as described by Ham and associates (1998), separated by polyacrylamide gel electrophoresis with $12 \%$ acrylamide and a Mighty Small II apparatus (Hoefer, San Francisco). Separated proteins were electrotransferred to Immobilon-P membranes (Millipore Co., Bedford, MA, U.S.A.) in a Hoefer transfer unit for $1 \mathrm{~h}$ at 80 $\mathrm{mA}$ at room temperature. Immunostaining with monoclonal M2 anti-FLAG antibody (Kodak) was performed using the Western-Light kit (Tropix, Bedford, MA, U.S.A.). Immunostaining with anti- $\beta$-galactosidase (Sigma, St. Louis) was also performed to detect the cytoplasmic control $\beta$-galactosidase. Membranes were exposed multiple times at time lengths ranging from $30 \mathrm{~s}$ to $20 \mathrm{~min}$ on Kodak OMAT X-ray films (Kodak) to record HopPtoA1, HopPtoA2, and $\beta$-galactosidase detection.

\section{GUS assays.}

CUCPB5114(pCPP5031), CUCPB5114(pCPP5032), CUCPB5135(pCPP5031), CUCPB5135(pCPP5032), CUCPB5136(pCPP5031) and CUCPB5136(pCPP5032) were grown in liquid AB-citrate (Chilton et al. 1974) at $30^{\circ} \mathrm{C}$ overnight. Cultures were diluted to an optical density of 0.3 and grown further for $6 \mathrm{~h}$. Then $100 \mu \mathrm{l}$ of liquid culture were used to determine GUS activity by the MUG (4-methylumbelliferyl $\beta$-D-glucuronic acid) method (Jefferson 1987) and a fluorometer Hoefer DyNA Quant 200 (Amersham Pharmacia Biotech Inc., San Francisco).

\section{Plant assays.}

Tobacco, tomato, and Arabidopsis thaliana plants were grown and inoculated with bacteria as described previously (Gopalan et al. 1996). For virulence assays, bacterial suspensions containing $10^{4} \mathrm{CFU} / \mathrm{ml}$ were infiltrated into tomato leaves and monitored daily over a 4-day period for symptom development and bacterial multiplication. Plants were maintained under high humidity conditions in an incubator at $20^{\circ} \mathrm{C}$ and with a $12 \mathrm{~h}$ light and $12 \mathrm{~h}$ dark cycle.

To determine whether hopPtoA1 can elicit the HR in tobacco, inhibit the HR elicited by pHIR11, or complement the $\mathrm{HR}^{-}$deficient phenotype of the pHIR11 hopPsyA mutant, a $3.0-\mathrm{kb}$ SphI fragment carrying the hopPtoAl operon was ligated into the $S p h \mathrm{I}$ site of a broad-host-range vector to construct pCPP2475, which should express hopPtoAl using its own promoter. $P$. fluorescens cells carrying a cosmid encoding the $P$. syringae pv. syringae 61 Hrp secretion system (pHIR11) or mutant derivatives of this cosmid (Alfano et al. 1996) was transformed with pCPP2475 and infiltrated into tobacco leaves.

\section{DNA gel blots.}

Total DNA $(2 \mu \mathrm{g})$ was digested with restriction enzymes and separated by electrophoresis on $0.5 \%$ gels. DNA was transferred to Immobilon-N membrane (Millipore Co.) and blots were hybridized at $50^{\circ} \mathrm{C}$ for $8 \mathrm{~h}$ in HYB-9 DNA hybridization solution (Gentra Systems, Research Triangle Park, NC, U.S.A.) with a $1.5-\mathrm{kb}$ hopPtoAl fragment that was amplified by PCR and then labeled with ${ }^{32} \mathrm{P}$ by using the Prime-It II kit (Stratagene). The membranes were washed four times in $1.0 \%$ sodium dodecyl sulfate (SDS) and $1 \times$ SSC $(1 \times$ SSC is $0.15 \mathrm{M}$ $\mathrm{NaCl}$ plus $0.015 \mathrm{M}$ sodium citrate) followed by two washes in $1.0 \%$ SDS and $0.2 \times$ SSC. Membranes were exposed to OMAT $\mathrm{X}$-ray film (Kodak) for 4 to $12 \mathrm{~h}$. Genomic DNA from $P$. syringae pathovars and other plant pathogenic bacteria was digested with EcoRI in experiments to determine if DNA sequences homologous to hopPtoAl were present in other plant pathogenic bacteria.

\section{Microscopy.}

P. syringae pv. tomato DC3000 wild-type, CUCPB5106, CUCPB5133, and CUCPB5134 strains were transformed with pGFP-TIR or pTB93F. Suspensions of each GFP-labeled strain at $\mathrm{OD}_{600}$ of 0.2 were prepared and diluted 1:20 with water. The diluted suspensions were infiltrated into Arabidopsis leaves with a blunt syringe, and the plants were incubated as indicated above for 40 hours. Ten fields per strain were observed with the $20 \times$ objective in a confocal laser-scanning microscope BioRad MRC600 (Bio-Rad Laboratories). The average diameter of the colonies and their volumes (assuming a sphere) were calculated for every field observed. The frequency of colonies smaller than $250 \mu \mathrm{m}^{3}$ and the frequency of colonies equal to or larger than $250 \mu \mathrm{m}^{3}$ of each strain was entered in a contingency table and the observed cell counts compared by applying the chi-square test. The statistical procedures were applied using PROC FREQ with the options TABLE and CHISQ of SAS version 8.2 for Windows (SAS Institute Inc., Cary, NC, U.S.A.).

\section{ACKNOWLEDGMENTS}

We thank K. Grace-Martin for statistical advice. This work was supported by NSF grant MCB-9982646. J. L. B. was partially supported by a Fulbright/COLCIENCIAS scholarship.

\section{LITERATURE CITED}

Alfano, J. R., and Collmer, A. 1996. Bacterial pathogens in plants: Life up against the wall. Plant Cell 8:1683-1698.

Alfano, J. R., and Collmer, A. 1997. The type III (Hrp) secretion pathway of plant pathogenic bacteria: Trafficking harpins, Avr proteins, and death. J. Bacteriol. 179:5655-5662.

Alfano, J. R., Bauer, D. W., Milos, T. M., and Collmer, A. 1996. Analysis of the role of the Pseudomonas syringae pv. syringae HrpZ harpin in elicitation of the hypersensitive response in tobacco using functionally non-polar hrpZ deletion mutations, truncated HrpZ fragments, and hrmA mutations. M. Microbiol. 19:715-728.

Alfano, J. R., Kim, H.-S., Delaney, T. P., and Collmer, A. 1997. Evidence that the Pseudomonas syringae pv. syringae hrp-linked hrmA gene encodes an Avr-like protein that acts in an hrp-dependent manner within tobacco cells. Mol. Plant-Microbe Interact. 10:580-588.

Alfano, J. R., Charkowski, A. O., Deng, W. L., Badel, J. L., PetnickiOcwieja, T., van Dijk, K., and Collmer, A. 2000. The Pseudomonas syringae Hrp pathogenicity island has a tripartite mosaic structure composed of a cluster of type III secretion genes bounded by exchangeable effector and conserved effector loci that contribute to parasitic fitness and pathogenicity in plants. Proc. Natl. Acad. Sci. U.S.A. 97:48564861 .

Altschul, S. F., Madden, T. L., Schaffer, A. A., Zhang, J., Zhang, Z., Miller, W., and Lipman, D. J. 1997. Gapped BLAST and PSI-BLAST: a new generation of protein database search programs. Nucleic Acids Res. 25:3389-3402.

Arnold, D. L., Gibbon, M. J., Jackson, R. W., Wood, J. R., Brown, J., Mansfield, J. W., Taylor, J. D., and Vivian, A. 2001. Molecular characterization of avrPphD, a widely-distributed gene from Pseudomonas syringae pv. phaseolicola involved in non-host recognition by pea (Pisum sativum). Physiol. and Mol. Plant Pathol. 58:55-62.

Chablain, P. A., Zgoda, A. L., Sarde, C. O., and Truffaut, N. 2001. Genetic and molecular organization of the alkylbenzene catabolism operon in the psychotropic strain Pseudomonas putida 01G3. App. and Environ. Microbiol. 67:453-458.

Charkowski, A. O., Alfano, J. R., Preston, G., Yuan, J., He, S. Y., and Collmer, A. 1998. The Pseudomonas syringae pv. tomato HrpW protein has domains similar to harpins and pectate lyases and can elicit the plant hypersensitive response and bind to pectate. J. Bacteriol. 180:5211-5217.

Chen, Z. Y., Kloek, A. P., Boch, J., Katagiri, F., and Kunkel, B. N. 2000. The Pseudomonas syringae avrRpt 2 gene product promotes pathogen virulence from inside plant cells. Mol. Plant-Microbe Interact. 13:1312-1321.

Chilton, M. D., Currier, T. C., Farrand, S. K., Bendich, A. J., Gordon, M. P., and Nester, E. W. 1974. Agrobacterium tumefaciens DNA and Ps8 bacteriophage DNA not detected in crown gall tumors. Proc. Natl. 
Acad. Sci. U.S.A. 71:3672-3676.

Collmer, A., Badel, J. L., Charkowski, A. O., Deng, W. L., Fouts, D. E., Ramos, A. R., Rehm, A. H., Anderson, D. M., Schneewind, O., van Dijk, K., and Alfano, J. R. 2000. Pseudomonas syringae Hrp type III secretion system and effector proteins. Proc. Natl. Acad. Sci. U.S.A. 97:8770-8777.

Cuppels, D. A. 1986. Generation and characterization of Tn5 insertion mutations in Pseudomonas syringae pv. tomato. App. Environ. Microbiol. 51:323-327.

Fouts, D. E., Abramovitch, R. B., Alfano, J. R., Baldo, A. M., Buell, C R., Cartinhour, S., Chatterjee, A. K., D’Ascenzo, M., Gwinn, M. L., Lazarowitz, S. G., Lin, N.-C., Martin, G. B., Rehm, A. H., Schneider, D. J., van Dijk, K., Tang, X., and Collmer, A. 2002. Genome-wide identification of Pseudomonas syringae pv. tomato DC3000 promoters controlled by the HrpL alternative sigma factor. Proc. Natl. Acad. Sci. U.S.A. 99:2275-2280.

Gage, D. J., Bobo, T., and Long, S. R. 1996. Use of green fluorescent protein to visualize the early events of symbiosis between Rhizobium meliloti and alfalfa (Medicago sativa). J. Bacteriol. 178:7159-7166.

Gopalan, S., Bauer, D. W., Alfano, J. R., Loniello, A. O., He, S. Y., and Collmer, A. 1996. Expression of the Pseudomonas syringae avirulence protein AvrB in plant cells alleviates its dependence on the hypersensitive response and pathogenicity (Hrp) secretion system in eliciting genotype-specific hypersensitive cell death. Plant Cell 8:1095-1105.

Grimm, C., Aufsatz, W., and Panopoulos, N. J. 1995. The hrpRS locus of Pseudomonas syringae pv. phaseolicola constitutes a complex regulatory unit. Mol. Microbiol. 15:155-165.

Habe, H., Kasuga, K., Nojiri, H., Yamane, H., and Omori, T. 1996. Analysis of cumene (isopropylbenzene) degradation genes from Pseudomonas fluorescens IP01. App. Environ. Microbiol. 62:4471-4477.

Ham, J. H., Bauer, D. W., Fouts, D. E., and Collmer, A. 1998. A cloned Erwinia chrysanthemi Hrp (type III protein secretion) system functions in Escherichia coli to deliver Pseudomonas syringae Avr signals to plant cells and to secrete Avr proteins in culture. Proc. Natl. Acad. Sci. U.S.A. 95:10206-102011.

Hanahan, D. 1985. Techniques for transformation of E. coli. Pages 109135 in: DNA Cloning: A Practical Approach. D. M. Glover, ed. IRL Press, Oxford, U.K.

He, S. Y., Huang, H. C., and Collmer, A. 1993. Pseudomonas syringae pv. syringae harpinPss: A protein that is secreted via the Hrp pathway and elicits the hypersensitive response in plants. Cell 73:1255-1266.

Hoyos, M. E., Stanley, C. M., He, S. Y., Pike, S., Pu, X.-A., and Novacky, A. 1996. The interaction of Harpin Pss $_{\text {with }}$ wiant cell walls. Mol. PlantMicrobe Interact. 9:608-616.

Huang, H.-C., Schuurink, R., Denny, T. P., Atkinson, M. M., Baker, C. J., Yucel, I., Hutcheson, S. W., and Collmer, A. 1988. Molecular cloning of a Pseudomonas syringae pv. syringae gene cluster that enables Pseudomonas fluorescens to elicit the hypersensitive response in tobacco plants. J. Bacteriol. 170:4748-4756.

Hutcheson, S. W., Bretz, J., Sussan, T., Jin, S. M., and Pak, K. 2001. Enhancer-binding proteins HrpR and HrpS interact to regulate hrp-encoded type III protein secretion in Pseudomonas syringae strains. J. Bacteriol. 183:5589-5598.

Huynh, T. V., Dahlbeck, D., and Staskawicz, B. J. 1989. Bacterial blight of soybean: Regulation of a pathogen gene determining host cultivar specificity. Science 245:1374-1377.

Innes, R. W., Bent, A. F., Kunkel, B. N., Bisgrove, S. R., and Staskawicz, B. J. 1993. Molecular analysis of avirulence gene avrRpt2 and identification of a putative regulatory sequence common to all known Pseudomonas syringae avirulence genes. J. Bacteriol. 175:4859-4869.

Innis, M. A., Gelfand, D. H., Sninsky, J. J., and White, T. J. 1990. PCR Protocols. Academic Press, San Diego, Calif.

Jefferson, R. A. 1987. Assaying chimeric genes in plants: The GUS gene fusion system. Plant Mol. Biol. Rep. 5:387-405.

Keen, N. T. 1990. Gene-for-gene complementarity in plant-pathogen interactions. Ann. Rev. Gen. 24:447-463.

Keen, N. T., Tamaki, S., Kobayashi, D., and Trollinger, D. 1988. Improved broad-host-range plasmids for DNA cloning in gram-negative bacteria. Gene 70:191-197.

Kim, J. F., and Beer, S. V. 1998. HrpW of Erwinia amylovora, a new harpin that contains a domain homologous to pectate lyases of a distinct class. J. Bacteriol. 180:5203-5210.

King, E. O., Ward, M. K., and Raney, D. E. 1954. Two simple media for the demonstration of pyocyanin and fluorescin. J. Lab. Clin. Med. 44:301-307.

Kjemtrup, S., Nimchuk, Z., and Dangl, J. L. 2000. Effector proteins of phytopathogenic bacteria: Bifunctional signals in virulence and host recognition. Curr. Opin. Microbiol. 3:73-78.

Lee, J., Klusener, B., Tsiamis, G., Stevens, C., Neyt, C., Tampakaki, A. P.,
Panoulos, N. J., Noller, J., Weiler, E. W., Cornelis, G. R., Manshield, J.

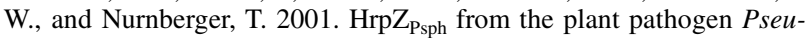
domonas syringae pv. phaseolicola binds to lipid bilayers and forms an ion-conducting pore in vitro. Proc. Natl. Acad. Sci. U.S.A. 98:289294.

Lorang, J. M., Shen, H., Kobayashi, D., Cooksey, D., and Keen, N. T. 1994. avrA and avrE in Pseudomonas syringae pv. tomato PT23 play a role in virulence on tomato plants. Mol. Plant-Microbe Interact. 7:508-515.

Miller, W. G., and Lindow, S. E. 1997. An improved GFP cloning cassette designed for prokaryotic transcriptional fusions. Gene 191:149-153.

Mudgett, M. B., and Staskawicz, B. J. 1999. Characterization of the Pseudomonas syringae pv. tomato AvrRpt2 protein: Demonstration of secretion and processing during bacterial pathogenesis. Mol. Microbiol. 32:927-941.

Noël, L., Thieme, F., Nennstiel, D., and Bonas, U. 2001. cDNA-AFLP analysis unravels a genome-wide $h r p G$-regulon in the plant pathogen Xanthomonas campestris pv. vesicatoria. Mol. Microbiol. 41:12711281.

Olsen, R. H., Debusscher, G., and McCombie, W. R. 1982. Development of broad-host-range vectors and gene banks-self-cloning of the Pseudomonas aeruginosa Pao chromosome. J. Bacteriol. 150:60-69.

Palleroni, N. J. 1984. Genus 1. Pseudomonas. Pages 141-199 in: Bergey's Manual of Systematic Bacteriology. N. R. Krieg and J. G. Holt, eds. Williams and Wilkins, Baltimore.

Prentki, P., and Krisch, H. M. 1984. In vitro insertional mutagenesis with a selectable DNA fragment. Gene 29:303-313.

Preston, G., Huang, H.-C., He, S. Y., and Collmer, A. 1995. The HrpZ proteins of Pseudomonas syringae pvs. syringae, glycinea, and tomato are encoded by an operon containing Yersinia ysc homologs and elicit the hypersensitive response in tomato but not soybean. Mol. PlantMicrobe Interact. 8:717-732.

Quandt, J., and Hynes, M. F. 1993. Versatile suicide vectors which allow direct selection for gene replacement in gram-negative bacteria. Gene 127:15-21.

Roine, E., Wei, W. S., Yuan, J., NurmiahoLassila, E. L., Kalkkinen, N., Romantschuk, M., and He, S. Y. 1997. Hrp pilus: An hrp-dependent bacterial surface appendage produced by Pseudomonas syringae pv tomato DC3000. Proc. Natl. Acad. Sci. U.S.A. 94:3459-3464.

Salanoubat, M., Genin, S., Artiguenave, F., Gouzy, J., Mangenot, S., Arlat, M., Billault, A., Brottier, P., Camus, J. C., Cattolico, L., Chandler, M., Choisne, N., Claudel-Renard, C., Cunnac, S., Demange, N., Gaspin, C., Lavie, M., Moisan, A., Robert, C., Saurin, W., Schiex, T., Siguier, P., Thébault, P., Whalen, M., Wincker, P., Levy, M., Weissenbach, J., and Boucher, C. A. 2002. Genome sequence of the plant pathogen Ralstonia solanacearum. Nature 415:497-502.

Sambrook, J., Fritsch, E. F., and Maniatis, T. 1989. Molecular Cloning: A Laboratory Manual, 2nd Edition. Cold Spring Harbor Laboratory Press, Cold Spring Harbor, NY, U.S.A.

Shan, L., He, P., Zhou, J.-M., and Tang, X. 2000. A cluster of mutations disrupt the avirulence but not the virulence function of AvrPto. Mol. Plant-Microbe Interact. 13:592-598.

Shen, H., and Keen, N. T. 1993. Characterization of the promoter of avirulence gene-D from Pseudomonas syringae pv. tomato. J. Bacteriol. 175:5916-5924.

van Dijk, K., Fouts, D. E., Rehm, A. H., Hill, A. R., Collmer, A., and Alfano, J. R. 1999. The Avr (effector) proteins HrmA (HopPsyA) and AvrPto are secreted in culture from Pseudomonas syringae pathovars via the Hrp (type III) protein secretion system in a temperature- and pH-sensitive manner. J. Bacteriol. 181:4790-4797.

Wei, Z. M., Laby, R. J., Zumoff, C. H., Bauer, D. W., He, S. Y., Collmer, A., and Beer, S. V. 1992. Harpin, elicitor of the hypersensitive response produced by the plant pathogen Erwinia amylovora. Science 257:85-88

Wood, J. R., Vivian, A., Jenner, C., Mansfield, J. W., and Taylor, J. D. 1994. Detection of a gene in pea controlling nonhost resistance to Pseudomonas syringae pv. phaseolicola. Mol. Plant-Microbe Interact. 7:534-537.

Xiao, Y. X., and Hutcheson, S. W. 1994. A single promoter sequence recognized by a newly identified alternate sigma-factor directs expression of pathogenicity and host-range determinants in Pseudomonas syringae. J. Bacteriol. 176:3089-3091.

Xiao, Y., Heu, S., Yi, J., Lu, Y., and Hutcheson, S. W. 1994. Identification of a putative alternate sigma factor and characterization of a multicomponent regulatory cascade controlling the expression of Pseudomonas syringae pv. syringae Pss61 hrp and hrmA genes. J. Bacteriol. 176:1025-1036.

Yamada, T., Lee, P. D., and Kosuge, T. 1986. Insertion sequence elements of Pseudomonas savastanoi: Nucleotide sequence and homology with Agrobacterium tumefaciens transfer DNA. Proc. Natl. Acad. Sci. U.S.A. 83:8263-8267. 
Yuan, J., and He, S. Y. 1996. The Pseudomonas syringae Hrp regulation and secretion system controls the production and secretion of multiple extracellular proteins. J. Bacteriol. 178:6399-6402.

\section{AUTHOR-RECOMMENDED INTERNET RESOURCES}

NCBI BLAST site: www.ncbi.nlm.nih.gov/BLAST/).

European Bioinformatics Institute, InterProScan sequence search page: www.ebi.ac.uk/interpro/scan.html.

Washington University in St. Louis, the Pfam database of protein domains and HMMs home page: pfam.wustl.edu/.

Imperial College of Science, Technology, and Medicine, 3D-pssm fold recognition server: www.sbg.bio.ic.ac.uk/ 3dpssm.

National Center for Research Resources, Learning, observing and outputting protein patterns (Loopp) site: www.tc.cornell.edu/reports/NIH/ resource/CompBiologyTools/loopp/. 